\title{
Broccoli growth, yield quantity and quality as affected by cobalt nutrition
}

\author{
Nadia Gad and M.R. Abd El-Moez \\ Plant Nutrition Dept., National Research Centre, Dokki, Giza, Egypt
}

\begin{abstract}
Two experiments were carried out included a pot preliminary greenhouse experiment to choose the most effective levels of cobalt on broccoli growth and yield and a field experiment to evaluate the vegetative growth, heads quantity and quality as well as nutrients content of broccoli (Brassica oleracea var.italica) as affected by using different levels of cobalt concentrations. The obtained results showed that the addition of $6 \mathrm{ppm}$ cobalt had a significant positive effect on broccoli growth, head yield and quality. Higher concentrations exerted hazards effect. The content of $\mathrm{Mn}, \mathrm{Zn}$ and $\mathrm{Cu}$ in heads increased with the increase in cobalt application. On the other hand, the opposite trend was observed with Fe. Cobalt rate at $6 \mathrm{ppm}$ increased the concentrations of $\mathrm{N}, \mathrm{P}$ and $\mathrm{K}$, but further increasing in cobalt concentrations addition decreased $\mathrm{N}, \mathrm{P}$ and $\mathrm{K}$ in broccoli heads.
\end{abstract}

Keywords: Cobalt, broccoli, , nutrients content., vegetative growth

\section{INTRODUCTION}

Broccoli belongs to family Brassicacea and considers a number of cole vegetable crops; which includes Cabbage, Cauliflower, and Chinese cabbage, broccoli, Brussels sprouts and kohlrabi. It well known that, broccoli has enormous nutritional and medicinal values due to its high contents of vitamins (A, B1, B2, $\mathrm{B} 5, \mathrm{~B} 6$ and $\mathrm{E}$ ), minerals ( $\mathrm{Ca}, \mathrm{Mg}, \mathrm{Zn}$, and $\mathrm{Fe}$ ) and antioxidant substances which prevent the formation of cancer causing agents (Beecher, 1994).

Broccoli, also known as calabrese in England and much of Europe. In Egypt, Broccoli still a grown in a very limited scattered areas and the total cultivated area is not exactly known. Eating larger portions may also have additional benefits, since broccoli is a rich source of many vitamins and minerals such as vitamin $\mathrm{A}$ and $\mathrm{C}$, carotenoids, fiber, calcium and folic acid (Michaud et al., 2002). Eating more than one serving of broccoli a week reduces the risk of prostate cancer by up to $45 \%$.

Recently, slight increased attentions towards extending the devoted cultivated areas and increasing the production of some untraditional vegetable crops including broccoli, through the pathway of nutrition, for local consumption and early exportation, have been directed.

Cobalt is a beneficial element for plant growth. In higher plants, cobalt also promoted many developmental processes including stem and coleoptile elongation opening of hypocotyl, leaf expansion and bud development (Howell and Skoog, 1975). It is also required for maintaining cucumber
(Nadia Gad, 2009), ground nut (Basu et al, 2006) and squash (Atta Aly, 1998) plant growth with low levels of its supply. Excess cobalt induces yield reduction, photoassimilates to roots and other sinks (Rauser and Samarakoon et al, 1980). Walser et al (1996) added, however, that cobalt application $(2.7 \mathrm{~kg} \mathrm{Co} / \mathrm{ha}$ soil) increased tomato leaf number as well as surface of chloroplasts per unit leaf area, leaf chlorophyll content, leaf area and rate of photosynthesis.

The aim of the present experiment is to investigate the response of growth, heads yield, chemical constituents as well as nutrients status of broccoli to different cobalt concentrations.

\section{MATERIALS AND METHODS}

\section{Experimental work:-}

Experiment (1): A pot greenhouse experiment was conducted during season 2008 at National Research Centre, Egypt to choose the most effective concentrations of cobalt on broccoli growth and yield. Seeds of broccoli (Brassica oleraceae L. var italica), family crucifer were sown in the nursery in foam trays filled with a mixture of peatmoss and sand (1:1) on the $1^{\text {st }}$ of September 2008. Trays being kept under greenhouse conditions with practicing all agricultural management required for production of broccoli seedlings. Plastic pots of diameter $40 \mathrm{~cm}$ were filled with sandy loam soil samples taken from Research and Production Station, of National Research Center El-Nubaria area. Seedling of five weeks-old with almost stem thickness were transplanted to each pot. Cobalt sulphate salt was used to enrich the soil with cobalt. The concentrations used were: $0,3,6,9,12$, 
15, 18, 21, 24, 27 and $30 \mathrm{ppm}$. All treatments were triplicated and arranged in a randomized complete block design. Irrigation with tap water was practiced to keep the soil almost at field capacity for 110- 120 days. After 60 days from transplanting, growth parameters were recorded according to Gabal et al (1984). After 90 days from transplanting, heads of broccoli were harvested, yield parameters were recorded according to Gabal et al (1984).
Soil analysis: Particle size distribution and moisture of the soil sample were determined as described by Black et al (1982). Soil pH, EC, cations and anions as well as organic matter, $\mathrm{CaCO}_{3} \%$, soluble, available micronutrients along with soluble, available and total cobalt were determined according to Cottenie et al (1982).

Some physical and chemical properties of El-Nubaria soil, Research and Production Station, of National Research Centre, are shown in Table (1).

Table 1: Some physical and chemical properties of the used soil at El-Nubaria farm.

\begin{tabular}{|c|c|c|c|c|c|c|c|c|c|}
\hline $\begin{array}{c}\text { Soil } \\
\text { properties }\end{array}$ & \multicolumn{5}{|c|}{ Particle size distribution \% } & \multicolumn{4}{|c|}{ Soil moisture constant $\%$} \\
\hline \multirow{4}{*}{ Physical } & Sand & \multicolumn{2}{|c|}{ Silt } & Clay & Texture & Saturation & FC & WP & AW \\
\hline & 68.7 & \multicolumn{2}{|c|}{24.5} & 6.8 & $\mathrm{~S} \mathrm{~L}$ & 32.0 & 19.2 & 6.1 & 13.1 \\
\hline & \multicolumn{3}{|c|}{$\mathrm{pH}^{\mathrm{a}}$} & \multicolumn{2}{|c|}{$\begin{array}{l}E C^{b} \\
\mathrm{dS} / \mathrm{m}\end{array}$} & \multicolumn{2}{|c|}{$\mathrm{CaCO}_{3} \%$} & \multicolumn{2}{|c|}{$\mathrm{OM}^{\mathrm{c}} \%$} \\
\hline & \multicolumn{3}{|c|}{7.8} & \multicolumn{2}{|c|}{0.18} & \multicolumn{2}{|c|}{7.07} & \multicolumn{2}{|c|}{0.16} \\
\hline \multirow{8}{*}{ Chemical } & \multicolumn{5}{|c|}{ Soluble cations (meq/l) } & \multicolumn{4}{|c|}{ Soluble anions (meq/l) } \\
\hline & $\mathrm{Ca}^{++}$ & \multicolumn{2}{|c|}{$\mathrm{Mg}^{++}$} & $\mathrm{K}^{+}$ & $\mathrm{Na}^{+}$ & $\mathrm{CO}_{3}=$ & $\mathrm{HCO}_{3}^{-}$ & $\mathrm{Cl}^{-}$ & SO4 \\
\hline & 3.00 & \multicolumn{2}{|c|}{2.00} & 0.32 & 2.09 & 0.00 & 1.41 & 0.70 & 5.30 \\
\hline & \multicolumn{2}{|c|}{$\begin{array}{c}\text { Total (mg/100 g } \\
\text { soil) }\end{array}$} & \multicolumn{3}{|c|}{ Available (mg/100 g soil) } & \multicolumn{4}{|c|}{ Available micronutrients ( ppm) } \\
\hline & \multicolumn{2}{|c|}{$\mathbf{N}$} & & & $\mathbf{K}$ & $\mathrm{Fe}$ & Mn & $\mathrm{Zn}$ & $\mathrm{Cu}$ \\
\hline & \multicolumn{2}{|c|}{15.0} & & & 16.0 & 7.8 & 3.3 & 1.86 & 4.0 \\
\hline & \multirow{2}{*}{\multicolumn{5}{|c|}{ Cobalt (ppm) }} & Soluble & \multicolumn{2}{|c|}{ Available } & Total \\
\hline & & & & & & 0.49 & 4. & & \\
\hline
\end{tabular}

a: Soil pH was measured in 1:2.5 soil-water suspension, b: EC was measured as $\mathrm{dSm}^{-1}$ in soil paste,

$S \mathrm{~L}:$ sandy loam.

FC, WP; AW= Field capacity, Wilting point and Available water.

Experiment (2): According to the results obtained from the preliminary experiment, it was found that cobalt concentrations of 3,6,9 and 12 ppm were more effective than the higher concentrations, therefore, a field experiment was conducted during successive season, 2009 at El-Nubaria soil, Research and Production Station of National Research Center, ElBehera Governorate, Egypt, to evaluate the vegetative growth, heads yield, heads chemical constituents and minerals composition of broccoli as affected by different concentration of cobalt i.e.3,6,9 and $12 \mathrm{ppm}$.

Seeds of broccoli were sown in the nursery in foam trays filled with mixture of peat moss and sand (1:1 by volume) on the $1^{\text {st }}$ September. Seedlings were transplanting in the open field at 45 days age in 2009 season. The experiment contains 5 plots. Each plot area was $5 \times 3 \mathrm{~m}^{2}$, consisting of three rows. Ten plants in each row (50 $\mathrm{cm}$ a part) were planted under drip irrigation system. Farmyard manure $(\mathrm{OM}=$
$32.6 \%$, total $\mathrm{N}=1.3, \mathrm{C} / \mathrm{N}$ ratio $=1: 6, \mathrm{pH}=6.3, \mathrm{EC}=$ $3.5 \mathrm{dS} . \mathrm{m}^{-1}, \mathrm{~K}=0.69 \%, \mathrm{P}=0.82 \% \mathrm{Fe}=420 \mathrm{ppm}, \mathrm{Mn}=$ $27.2 \mathrm{ppm}, \mathrm{Zn}=15.5 \mathrm{ppm}, \mathrm{Cu}=12.6 \mathrm{ppm}$ ) at a rate of $10 \mathrm{~m}^{3} / \mathrm{fed}$ was added during soil preparation. Ammonium nitrate $(33.5 \% \mathrm{~N})$ at a rate $100 \mathrm{~N}$ unit/fed; superphosphate calcium $\left(15.5 \mathrm{P}_{2} \mathrm{O}_{5} \%\right)$ at a rate of 60 unit $\mathrm{P}_{2} \mathrm{O}_{5} /$ fed and potassium sulphate $\left(48 \% \mathrm{~K}_{2} \mathrm{O}\right)$ at a rate of 50 unit $\mathrm{K}_{2} \mathrm{O}$ /fed were split into three equal doses and applied at 3,6 and 9 weeks after transplanting.

Measurement of plant growth parameters: After 60 days from transplanting end of vegetative growth, growth parameters i.e. plant height, branches and leaves number per plant, leaves area as well as fresh and dry weight of both shoots and roots (3 plants from each treatment) were recorded according to Gabal et al (1984). At mature stage, after 90 days from transplanting, broccoli heads were harvested (three harvests) to record heads number/plant, heads weight, heads diameter, yield of the $1^{\text {st }} 2^{\text {nd }}$ and $3^{\text {rd }}$ harvests and total yield according to Gabal et al (1984). 
Measurement of head quality: Chemical constituents i.e. TSS, protein, sugars, phenols, titrtable acidity as well as vitamins $A$ and $C$ were determined according to the methods described by A.O.A.C. (1990). Nutrients content were determined according to Cottenie et al (1982).

Statistical analysis of the obtained data was subjected to standard analysis of variance procedure. The values of LSD were calculated at $5 \%$ according to Snedecor and Cochran (1984).

RESULTS AND DISCUSSIONS

Vegetative growth: Data presented in Table (2) showed that addition of different cobalt levels $(3,6,9$, and $12 \mathrm{ppm}$ ) to the growth media significantly increased plant height, number of branches and leaves per plant and leaves area of broccoli plants compared with the control. Data also reveled that all cobalt levels used significantly promoted both fresh and dry weights compared with untreated plants. The superior recorded results of the previously mentioned parameters were obtained under treatment of $6 \mathrm{ppm}$. Higher cobalt concentrations, namely 9 and $12 \mathrm{ppm}$, resulted in slight significant reduction in all growth parameters of broccoli compared with the treatment of $6 \mathrm{ppm}$ but it still higher than the control. These observations are consistent with previous report obtained by Nadia Gad (1989), who stated that low cobalt levels had a significant synergestic effect to induce some endogenous hormones due to Auxins and Gebberelenes and decrease the activity of some enzymes such as peroxidase and catalase in plants and hence increasing the anabolism rather than catabolism while the higher cobalt levels increased the catabolism rather than anabolism.

Table 2 Vegetative growth of broccoli as affected by different cobalt concentrations.

\begin{tabular}{|c|c|c|c|c|c|c|c|c|}
\hline \multirow{2}{*}{$\begin{array}{l}\text { Cobalt } \\
\text { treatment } \\
(p p m)\end{array}$} & \multirow{2}{*}{$\begin{array}{l}\text { Plant } \\
\text { height } \\
(\mathrm{cm})\end{array}$} & Branches & \multirow{2}{*}{ Leaves } & \multirow{2}{*}{$\begin{array}{c}\text { Leaves } \\
\text { area }\left(\mathrm{cm}^{2}\right)\end{array}$} & \multicolumn{2}{|c|}{ Fresh weight (g) } & \multicolumn{2}{|c|}{ Dry weight (g) } \\
\hline & & No./plant & & & Shoot & Root & Shoot & Root \\
\hline control & 54.7 & 8 & 20 & 336 & 439 & 36.9 & 46.6 & 9.55 \\
\hline 3 & 56.6 & 9 & 24 & 404 & 486 & 41.0 & 51.7 & 10.60 \\
\hline 6 & 60.3 & 11 & 29 & 488 & 548 & 46.2 & 58.0 & 15.30 \\
\hline 9 & 58.0 & 10 & 25 & 420 & 512 & 43.0 & 54.8 & 12.80 \\
\hline 12 & 55.5 & 9 & 23 & 387 & 506 & 42.3 & 53.7 & 10.90 \\
\hline LSD 5\% & 2.1 & 2 & 2 & 24 & 32 & 1.1 & 1.3 & 0.82 \\
\hline
\end{tabular}

Heads yield of broccoli: The present data in Table (3) concerning with the yield parameters of broccoli as affected by different levels of cobalt indicated that all cobalt doses gave a significant positive effect for the yield parameters i.e. heads number per plant, heads diameter and heads weight of broccoli compared to the control. Cobalt at $6 \mathrm{ppm}$ gave the superior heads yield components at different harvests. Increasing cobalt addition in plant media more than $6 \mathrm{ppm}$ (9 and $12 \mathrm{ppm}$ ) reduced the positive effect on yield of the broccoli. These observations are consistent with the previous reports obtained by Nadia Gad et al (2008) who stated that the lower doses of cobalt resulted in maximum growth and yield of cucumber plants as compared with the higher ones. It is evident that cobalt rate at
$6 \mathrm{ppm}$ increased the heads yield of broccoli by 66.3 , 66.9 and $68.7 \%$ for the first, second and third harvests, respectively.

Chemical constituents: Data presented in Table (4) reveled that all cobalt levels showed favorable effect on some physiological parameters such as TSS, protein, sugars, titrable acidity and phynoles as well as vitamins " $\mathrm{A}$ " and " $\mathrm{C}$ " in broccoli heads. Results indicated that all the mentioned parameters significantly increased by the addition of different cobalt levels (3, 6, 9, and $12 \mathrm{ppm})$ as compared with the control. The highest values of all the studied parameters are obtained by using cobalt level at 6 ppm (Table 4). 
Table 3: The heads yield of broccoli as affected by different cobalt concentrations.

\begin{tabular}{|c|c|c|c|c|c|c|c|}
\hline \hline $\begin{array}{c}\text { Cobalt } \\
\text { treatments } \\
(\mathrm{ppm})\end{array}$ & $\begin{array}{c}\text { Heads } \\
\text { No./plant }\end{array}$ & $\begin{array}{c}\text { Heads } \\
\text { diameter } \\
(\mathrm{cm})\end{array}$ & \multirow{2}{*}{$\begin{array}{c}\text { Heads } \\
\text { weight } \\
\text { g/plant }\end{array}$} & \multicolumn{4}{|c|}{ Heads weight at different harvests (ton /fed) } \\
\cline { 6 - 9 } & 4 & 13.2 & 204 & 1.84 & 1.78 & 1.63 & 5.25 \\
\hline \hline control & 5 & 14.6 & 262 & 2.23 & 2.38 & 1.96 & 6.57 \\
\hline 3 & 6 & 16.5 & 306 & 3.06 & 2.97 & 2.75 & 8.78 \\
\hline 6 & 5 & 15.3 & 286 & 2.69 & 2.59 & 2.37 & 7.65 \\
\hline 12 & 5 & 14.1 & 253 & 2.28 & 2.20 & 2.03 & 6.51 \\
\hline \hline LSD 5\% & 1 & 1.1 & 26 & 0.23 & 0.16 & 0.27 & 0.34 \\
\hline \hline
\end{tabular}

Table 4: Chemical constituents of broccoli heads as affected by different cobalt concentrations.

\begin{tabular}{|c|c|c|c|c|c|c|c|}
\hline \multirow{2}{*}{$\begin{array}{l}\text { Cobalt } \\
\text { treatments } \\
(p p m)\end{array}$} & TSS & Protein & Sugar & Phenoles & $\begin{array}{l}\text { Titrable } \\
\text { acidity }\end{array}$ & Vitamin (A) & Vitamin (C) \\
\hline & \multicolumn{5}{|c|}{$\%$} & \multicolumn{2}{|c|}{$\mathrm{mg} / 100 \mathrm{gm}$ fresh tissue } \\
\hline control & 5.13 & 9.85 & 4.61 & 6.44 & 0.49 & 16.5 & 78.2 \\
\hline 3 & 5.82 & 11.91 & 4.88 & 6.92 & 0.44 & 16.9 & 78.9 \\
\hline 6 & 6.70 & 19.41 & 5.13 & 7.45 & 0.40 & 17.4 & 80.6 \\
\hline 9 & 6.33 & 18.09 & 4.85 & 7.02 & 0.37 & 17.0 & 78.2 \\
\hline 12 & 5.75 & 11.79 & 4.56 & 6.87 & 0.33 & 16.8 & 77.6 \\
\hline LSD 5\% & 0.14 & 0.17 & 0.21 & 0.37 & 0.06 & 0.3 & 0.6 \\
\hline
\end{tabular}

It is evident that cobalt rate at $6 \mathrm{ppm}$ increased the contents of : TSS by $30.6 \%$, protein by $97 \%$, sugars by $11.3 \%$, phynoles by $15.7 \%$, Vitamin "A" by $5.5 \%$ and vitamin "C" as L-Ascorbic acid by $3.07 \%$. These components are essential to human growth, normal physiological functions. Moreover, vitamin " $\mathrm{C}$ " is an antioxidant and its necessary to several metabolic processes (Grifiths and Lunec, 2001). Data also showed that, increasing the levels of cobalt above 6 ppm (9 and $12 \mathrm{ppm}$ ) led to significant reduction in all the mentioned parameters. However, these values were higher than those obtained by the control. The obtained results revealed that cobalt gave a positive role on the studied chemical constituents of broccoli heads and came in harmony with those obtained by Nadia Gad and Hala Kandil (2008) who found that cobalt had a positive effect for TSS, protein, sugars, phenoles as well as vitamin " $\mathrm{A}$ " and " $\mathrm{C}$ " of sweet potato roots while increasing cobalt levels resulted in significant adverse effect. On the other hand, titrable acidity as citric acid showed negative response to all levels of cobalt which mean increasing the heads quality of broccoli.

Table 5: Minerals composition of broccoli heads as affected by different cobalt concentrations.

\begin{tabular}{|c|c|c|c|c|c|c|c|c|c|c|}
\hline \hline $\begin{array}{c}\text { Cobalt } \\
\text { treatments } \\
(\mathrm{ppm})\end{array}$ & \multicolumn{4}{|c|}{ Macronutrients (\%) } & \multicolumn{4}{c|}{ Micronutrients (ppm) } & \multicolumn{2}{c|}{ Cobalt (ppm) } \\
\cline { 2 - 12 }$y$ & $\mathrm{~N}$ & $\mathrm{P}$ & $\mathrm{K}$ & $\mathrm{S}$ & $\mathrm{Mn}$ & $\mathrm{Zn}$ & $\mathrm{Cu}$ & Fe & Shoots & Heads \\
\hline \hline control & 1.58 & 0.256 & 1.63 & 0.791 & 59.6 & 34.5 & 29.4 & 163 & 2.80 & 1.00 \\
\hline 3 & 1.83 & 0.288 & 1.95 & 0.821 & 61.6 & 37.8 & 32.0 & 156 & 5.01 & 1.87 \\
\hline 6 & 3.19 & 0.311 & 2.41 & 1.102 & 65.7 & 41.5 & 35.4 & 150 & 8.24 & 3.05 \\
\hline 9 & 2.90 & 0.290 & 2.02 & 0.956 & 67.2 & 43.3 & 36.6 & 143 & 11.30 & 4.90 \\
\hline 12 & 1.89 & 0.276 & 1.89 & 0.883 & 68.7 & 45.7 & 38.4 & 137 & 14.60 & 6.98 \\
\hline \hline LSD 5\% & 0.22 & 0.027 & 0.20 & 0.126 & 1.13 & 2.6 & 2.8 & 4 & 3.2 & 0.62 \\
\hline \hline
\end{tabular}


Mineral composition of heads

Nitrogen, $\mathbf{P}$ and $\mathbf{K}$ contents: Data in Table (5) showed that, all cobalt doses significantly increased the content of $\mathrm{N}, \mathrm{P}$ and $\mathrm{K}$ as compared with the control. Cobalt rate at $6 \mathrm{ppm}$ gave the highest values of $\mathrm{N}, \mathrm{P}$ and $\mathrm{K}$, while increasing cobalt levels more than $6 \mathrm{ppm}$ (9 anfd $12 \mathrm{ppm}$ ) in plant media gave an adverse effect. Besue et al (2006) stated that the application of low levels of cobalt significantly increased the status of macronutrients ( $N, P$ and $K$ ) in ground nut plants as compared with the higher levels

Manganese, Zinc and $\mathrm{Cu}$ content: Presented data in Table (5) revealed that, all cobalt levels, significantly promotive effect for better status of $\mathrm{Mn}$, $\mathrm{Zn}$ and $\mathrm{Cu}$ in heads of broccoli compared with the control. Higher cobalt doses (9 and $12 \mathrm{ppm}$ ) also increased the content of $\mathrm{Mn}, \mathrm{Zn}$ and $\mathrm{Cu}$. These elements play a vital role as catalyst elements. These results are in agreement with those obtained by Nadia Gad (2009) who stated that cobalt level of $12.5 \mathrm{ppm}$ gave the highest values of the $\mathrm{Mn}, \mathrm{Zn}$ and $\mathrm{Cu}$ in canola seeds. Sulpher took the same trend as the other elements.

Cobalt and iron contents: Results in Table (5) clearly indicated that, increasing cobalt concentrations in broccoli plants media increased cobalt content in broccoli heads where cobalt concentrations are still in the safety limits for human. Cobalt content of broccoli shoots were generally increased approximately from 2-3 folds that of heads. These data are in harmony with those obtained by Nadia Gad (2005) who reported that cobalt content of tomato shoots were generally increased to $2-3$ folds that of fruits. Data in Table (5) also clearly indicated that, increasing cobalt doses in plant media from 3 to $12 \mathrm{ppm}$ resulted in a progressive depression effect on iron content in broccoli heads. This may be explained on the basis obtained by Bisht (1991) and Nadia Gad et al (2008) who referred to certain antagonistic relationships between the two elements ( $\mathrm{Co}$ and $\mathrm{Fe}$ ), and added that the relative response of iron to the control indicated continuous of this elements. They also added that the hazardous effect of cobalt being severely involved in wilting appearance and reduction for net photosynthesis processes.

\section{CONCLUSION:}

Cobalt content of broccoli shoots were increased approximately from $2-3$ folds that of heads levels at $12 \mathrm{ppm}$ cobalt treatment (6.98 ppm.) which is below the dangerous level, since the daily consumption of broccoli heads does not exceed a few grams . Young (1983) found that the daily cobalt requirements for human nutition could reach 8 ppm without health hazard.

\section{REFERENCES}

A.O.A.C. (1990). Official Methods of Analysis, Association of Official Agricultural Chemist $20^{\text {th }}$ Ed. Washington DC, USA.

Atta Aly, M.A. (1998). Soaking summer squash seeds in low concentrations of cobalt solution before sowing increased plant growth, femaleness and fruit yield via increasing plant ethylene level. J. Plant Growth Regul. 17: 25-32.

Besu, M.; P.B.S Bhadoria and S.C. Mahapatra (2006). Influence of microbial culture in combination with micronutrient in improving the groundnut productivity under alluvial soil of India. Acta Agric. Slovenica, 78-2, pp 435-444.

Beecher, C. (1994). Cancer preventive properties of varieties of Brassica aleracea: A review . Am. J. Clin. Nutr. 59: 116-1170.

Bisht, J.C. (1991). Interrelations between mineral plant tissues iron and cobalt. Pescu, Agropecu. Bras. 16: 739-746.

Black, C.A.; D.D. Evans; L.E. Ensminger ; G.L. White and F.E. Clarck (1982). "Methods of Soil Analysais" Part 2. Agron. Inc. Madison. Wisc.

Cottenie, A. M. Verloo, L. Kiekens, G. Velgh and R. Camerlynck (1982). Chemical Analysis of Plants and Soils. P 44-45. State Univ. Ghent Belgium, 63.

Gabal, M.R., I.M. Abd-Allah; F.M. Hass and S. Hassannen (1984). Evaluation of some American tomato cultivars grown for early summer production in Egypt. Annuals of Agric. Sci. Moshtohor, 22: 487-500.

Grifithus, H.R. and Lunec, J. (2001). 'Ascorbic acid in the 21st Century - more than a simple antioxidant " Enivron. Toxicol, and Pharmacol., 10:173-182.

Howell, R.W. and F. Skoog (1975). Effect of adenine and other subsurfaces on growth of excised pisum epicotyls cultured in Vitro. Am. J. Bot. 49: 645-649.

Michaud, D.S.; P. Pietnen; R.R. Taylor, M. Virtanen, J. Vitramo and D. Albanes (2002). Intakes of fruits and vegetables, carotenoids and vitamins $A, E, C$ in relation to the risk of bladder cancer in the ATBC cohort study. Br.J. Cancer, 87: 960-965.

Nadia Gad (2005). Effect of cobalt on tomato growth, yield and fruit quality. Egypt. J. Appl. Sci., 20(4) 260-270.

Nadia Gad (2009). Improving quantity and quality of canola oil yield through cobalt nutrition. Developmental Biology and Tissue Engineering (In press). 
Agric. Biol. J. N. Am., 2011, 2(2): 226-231

Nadia Gad (1989). Effect of cobalt on growth and mineral composition of plant. M.Sci. Thesis, Faculty Agric. Ain Shams Univ. Egypt.

Nadia Gad and Hala Kandil (2008). Response of sweet potato (Ipomoea batatas L.) plants to different levels of cobalt. Australian J. Basic and Applied Sci 2 (4): 949955.

Nadia Gad; A.M. Shafie and M.S. Abdel-Fatah (2008). Effect of cobalt on cucumber growth, fruits yield and mineral composition. J. Agric.Sci. Mansura Univ. 33(1): 909-915.
Rauser, W.E. and A.B. Samarakoon (1980). Vein loading of phasealus vulgaris exposed to excess cobalt, Nickl and Zinc. Plant Physiol. 65: 578-583.

Snedecor, G.W. and W.G. Cochran. (1982). Statistical Method. $7^{\text {th }}$ Edn. lowa State Univ. Press., USA.

Walser, R.H., V.D. Jolley and T.D. Davis (1996). Effect of cobalt application on structural organization of photosynthetic apparatus of tomato leaves. Plant Nutr. 19:358-368.

Young, S.R. (1983). Recent advances on cobalt human nutrition. Victoria Pochvovedeniye, 3:59-62. 